\title{
OBITUARY
}

\section{ARTHUR STANLEY TRITTON}

Arthur Stanley Tritton was born on 25 February 1881. His father was senior pastor of the Congregational Church at Great Yarmouth, but illness compelled him to resign five years later and the family moved to Wandsworth. Tritton was educated at the United Westminster Schools and took his London Intermediate B.A. in English in 1899. Next year he graduated externally at London, matriculated as a non-collegiate student at Oxford, and was admitted to Mansfield College. He took Honours in Theology in 1904, graduated in 1906, and then spent a year in the Congregational ministry at Morcombelake near Lyme Regis. In 1907 he returned to Oxford as Kennicott Junior Hebrew Scholar. He then spent two semesters at Göttingen, studying under Wellhausen, before joining the staff of the Friends' Mission School at Brummana in Lebanon in 1909. From 1911 to 1916 he was Assistant to the Professor of Hebrew and Semitic Languages at Edinburgh. He spent some months in Aden as a missionary, took his London M.A. in Arabic as a private student in 1914 and his D.Litt. at Edinburgh in 1918, and became Assistant to the Professor of Hebrew at Glasgow in 1920. Next year he was appointed Professor of Arabic at Aligarh; an article which he contributed to the Encyclopaedia of Islam on Aligarh includes a candid comment on the university which he served for the next nine years. In 1931 he was made Lecturer in Arabic at the Schnol. Two years later he was promoted to Reader and in 1938 he succeeded Gibb as Professor of Arabic and Head of Department. He retired in 1946 but continued to teach for a time as a part-time lecturer. He was made an Honorary Fellow of the School in 1946 and Professor Emeritus in the following year. He died on 8 November 1973.

Tritton was a painstaking teacher, a helpful colleague, and an industrious author. He published six books, The rise of the Imams of Sanaa (1925), based on his doctoral thesis, The Caliphs and their non-Muslim subjects (1930), which has been reprinted and translated into Arabic, Teach yourself Arabic (1947), Muslim theology (1947), Islam : beliefs and practices (1951), and Materials on Muslim education in the Middle Ages (1957). He contributed numerous articles to academic periodicals, especially to this Bulletin and the Journal of the Royal Asiatic Society, and to encyclopaedias, acting on occasion as English editor of the Encyclopaedia of Islam in Gibb's absence. He reviewed 140 books for the Bulletin alone. His scholarship was wide and accurate rather than profound. He did not specialize. He was happy to investigate any topic that caught his attention within the vast scope of Arabic studies, and he did some work in Hebrew and Syriac. Generally he was content to ascertain, record, and arrange facts, refraining from analysis and interpretation. He hated cant and jargon. In his reviews he could dismiss important books if they were marred by pompous neologisms, obscure syntax, or mistakes in grammar and spelling. Advancing years affected slightly the quantity but not the quality of his publications, or the 
unmistakable staccato style in which he wrote. Some of his work is still in the press.

During his long retirement he was a constant visitor to the School, to the Oriental Students' Room at the British Museum, and to meetings of the Royal Asiatic and Royal Central Asian Societies. Many members of the School will remember him with affection and will recall the frequent and generous hospitality and the inexhaustible store of anecdotes with which he liked to entertain them at the Athenaeum. In spite of increasing frailty his neat appearance and precise delivery gave an impression that was almost dapper. Peu de gens, said La Rochefoucauld, savent être vieux. Tritton was certainly one of those few.

C. F. BECKINGHAM 